UDC 629.463.62.018- 048.35

\title{
O. H. REIDEMEISTER ${ }^{1}$, V. O. KALASHNYK ${ }^{2 *}$, O. A. SHYKUNOV ${ }^{3}$
}

${ }^{1}$ Dep. «Cars and Cars Facilities», Dnipropetrovsk National University of Railway Transport named after Academician V. Lasaryan, Lasaryan St., 2, Dnipropetrovsk, Ukraine, 49010, tel./fax +38 (056) 793 19 16, e-mail reidemeister@mail.ru, ORCID 0000-0001-7490-7180

$2^{*}$ Dep. «Cars and Cars Facilities», Dnipropetrovsk National University of Railway Transport named after Academician V. Lasaryan, Lasaryan St., 2, Dnipropetrovsk, Ukraine, 49010, tel./fax +38 (056) 793 19 16, e-mail kv47@i.ua, ORCID 0000-0002-8073-4631

${ }^{3}$ Dep. «Cars and Cars Facilities», Dnipropetrovsk National University of Railway Transport named after Academician V. Lasaryan, Lasaryan, St. 2, Dnipropetrovsk, Ukraine, 49010, tel./fax +38 (056) 79319 16, e-mail tri_s@ua.fm, ORCID 0000-0001-8256-2634

\section{MODERNIZATION AS A WAY TO IMPROVE THE USE OF UNIVERSAL CARS}

Purpose. The main design requirements of the modernized cars are those allowing reduction of operating costs and improvement of economic efficiency of their use. Due to the relevance of this subject the work presents the complex of conducted research, which will allow in prospect to use the universal flatcar, converted according to the Technical specifications TU 3182-065-71390252-2911 for container service. The research includes: evaluation of strength, fatigue safety of the design elements and conformity assessment of the strength characteristics of the modernized flatcar elements to the regulatory documents. Methodology. The analysis covers the use of specialized and universal rolling stock for transportation of containers, as well as the issues of modernization of universal cars. The strength of the flatcar bearing structure is evaluated based on the complex of numerical and experimental studies. The experimental part includes the static, repair load and impact tests. The car strength qualities and the fatigue safety are evaluated on the basis of calculated and experimental data. Findings. The conducted static, repair load and impact tests, given the quasi-static longitudinal forces, allowed the evaluation of the car structure strength according to the regulatory documents. The calculated and experimental data make it possible to assess the fatigue safety of structural elements. The present work is completed by obtaining the results that allow performing reasonable re-equipment of universal flatcars with baseplates with fitting stops to fasten the containers. Originality. The results of calculated and experimental studies showed that the modernized flatcars meet the conditions of strength and have sufficient fatigue safety factor. This makes it possible to recommend the re-equipment of universal flatcars for all car-repair enterprises that submitted the prototypes. Practical value. The complex of works was conducted that demonstrated the possibility of re-equipment of universal flatcars for the transportation of large containers. Part of the car fleet, kept in reserve, with little material costs can be transferred to the operational fleet. The modernization - re-equipment of universal flatcars with stationary specialized devices will increase the car usability coefficient.

Keywords: flatcar; container; centre sill; structural strength; static tests; longitudinal loads; impact tests; fitting stop; stress; strength evaluation

\section{Introduction}

In the last decade the average annual growth in global container traffic reached 3\%. This growth requires augmentation of the rolling stock with cars for container service. This can be carried out by specialized container service cars and using the universal rolling stock (gondola cars, flatcars).

The car-building enterprises such as CJSC «Protractor-Wagon», CJSC «UK BMZ», OJSC «Azov», OJSC «Altaivagon», OJSC «Dneprovagonmash», OJSC «ZMK», OJSC «KVSZ», OJSC «Ruzkhimmash», OJSC «Tverskoy VSZ», OJSC «Transmash» offer a wide range of $40,60,80$-foot cars for container service [5], [6], [7], [8]. Further to the work on improvement of such cars OJSC «Azovmash» and OJSC NVC «Vagony» conducted the research and developed the design of modern articulated flatcars for container service [1], [5], 11]. However, the completion of the rolling stock with new flatcars is not a quick process both technically and economically.

Therefore, there is a question of using the cars of existing operating fleet.

Analysis of the inventory rolling stock of Russian Railways, presented in [12], showed that a largest number of cars in reserve are flatcars 
(37\%), whose normative service life (32 years) has not expired and there is an opportunity to use them for further operation after the modernization.

Problems of modernization and re-equipment of cars for transportation of containers, pipes, timber, etc. were the most substantively considered by OJSC NVC «Vagony» [2], [3], [4], [12]. Here, for several years they have been conducted the research of ways for modernization (design study) and justification of the further operation of modernized cars. One of the developments is the modernization of flatcars of models 13-401 and 13-4012 for transportation of large containers. They developed Technical specifications TU 3182065-71390252-2911 and carried out a wide range of theoretical and experimental studies, including: car negotiation, dynamic qualities, car design stability, static and impact strength tests. The research results lead to approval by Russian Railways of $\mathrm{TU}$ that were recommended for widespread use. The modernization of universal flatcars for transportation of heavy tonnage containers implies the equipment of cars with baseplates with fitting stops to fasten the containers (Fig. 1). The modernized flatcars are marked 13-401-50 and 13-4012-50 respectively. The production of equipment is agreed in time with the scheduled type of repair (roundhouse servicing or overall repair).

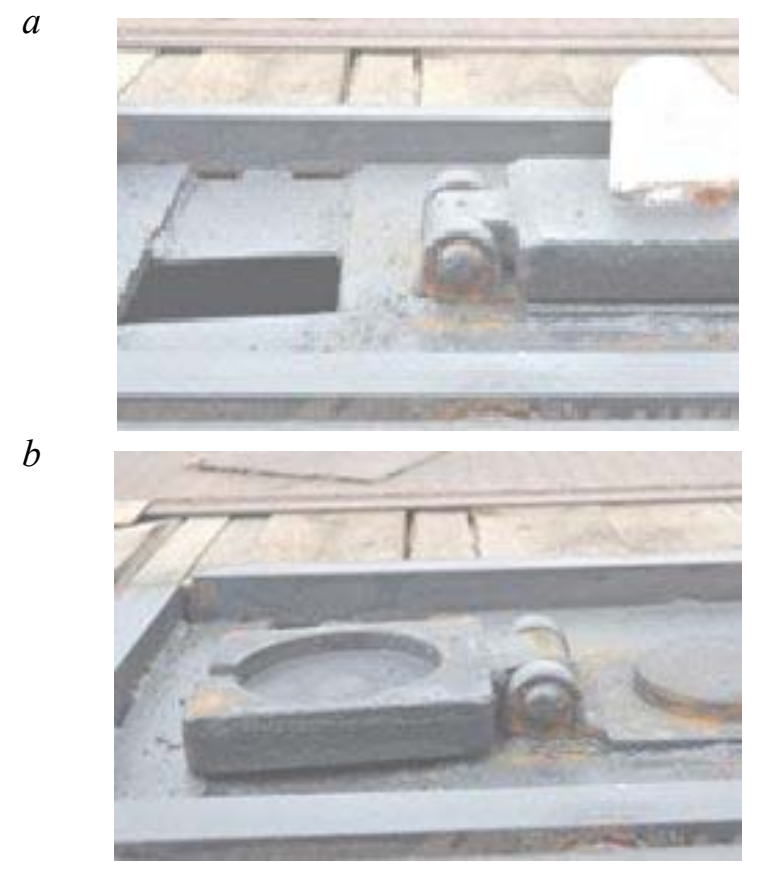

Fig. 1. Arrangements of fitting stop
Herewith, the enterprise producing the repair should be included in the list of enterprises that have the right to re-equip the flatcars of these models.

The figure shows that the elevated fitting stop (Fig. 1. a) allows placing of containers, while the lowered stop (Fig.1.b) - a wide range of goods. Also, such arrangement of baseplates does not prevent from placing a wide range of goods when the fitting stops are lowered. Thus, the flatcar can be used for transporting cargo in both directions, which greatly increases its efficiency.

\section{Purpose}

The enterprise, which re-equips the flatcars in accordance with TU 3182-065-71390252-2911, should produce a prototype, conduct acceptance testing, and an accredited test centre - preliminary, periodic and standard tests. RPE «Vagonnik» engaged Dnipropetrovsk National University of Railway Transport (DNURT) to perform the tests. Furthermore RPE specialists and employees took part in tests performance, including: static strength tests, collision strength tests and calculationexperimental evaluation of the structure fatigue safety.

There were tested 6 flatcars, which undergone modernization in various car repair depots of OJSC «VRK», located on the territory of the East Siberian, Far Eastern, Trans-Baikal, North and South Urals Railways.

\section{Methodology}

Prior to the tests the tensoresistors (sensors) were stuck onto the bearing elements of the car frame. Herewith one side of the car (with respect to the longitudinal symmetry axis) was the primary one, and the other - the control one (one or two sensors in the section). Fig. 2 shows the arrangement of sections on the car frame and designation (abbreviation) of elements. In total there are 12 sections on the left and the right sides (with respect to the longitudinal axis) of the car, which house 44 sensors. Designations of elements are as follows: CS - centre sill, SS - side sill, SB span bolster, LB - longitudinal beam, DG diagonal, LBM - longitudinal beam in the car middle. 


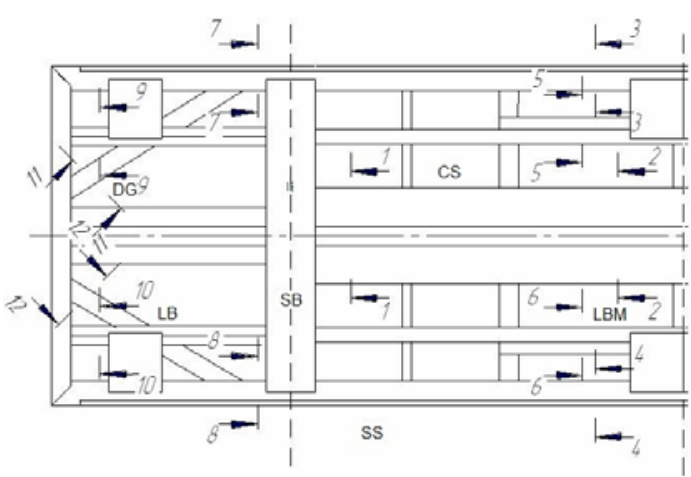

Fig. 2. Arrangement of sections on the flatcar frame

The main purpose of the static strength test was the compliance check of flatcar structure element strength index with the requirements of regulatory documentation.

There were conducted static vertical (a) and repair load tests (Fig. 3);

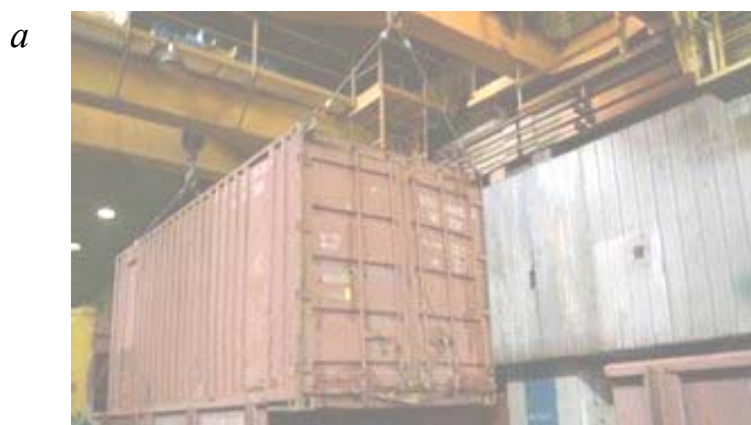

$b$

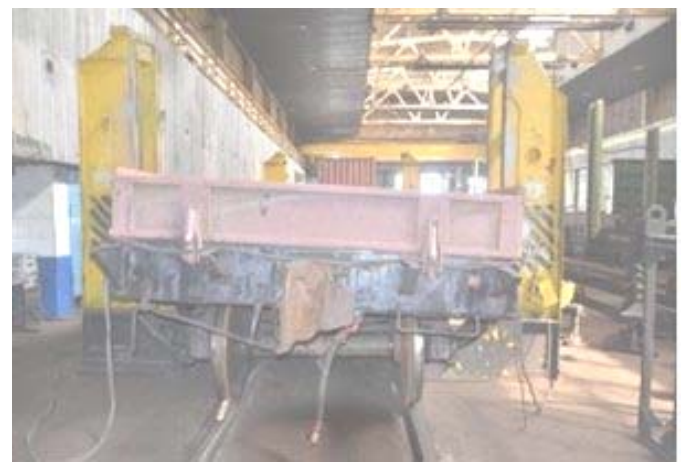

Fig. 3. Static vertical (a) and repair (b) load diagrams

The static vertical load was tested by way of loading flatcar with two 20 -foot containers with a gross mass of 23.5 tons and 24.5 tons. During the test the stresses in the frame elements were fixed when the car was empty and laden.

The repair load tests included the following modes:

- Lifting of laden car using both ends of the span bolster; bolster;

- Lifting of laden car using one end of the span

- Lifting of empty car using the opposite ends of the span bolster (by diagonal).

The collision strength tests were conducted by the hammer-car locomotive rolling onto the prototype car, standing in the retaining wall (Fig. 3 ). The wall was formed by 5 loaded cars with total weight of more than 300 tons.

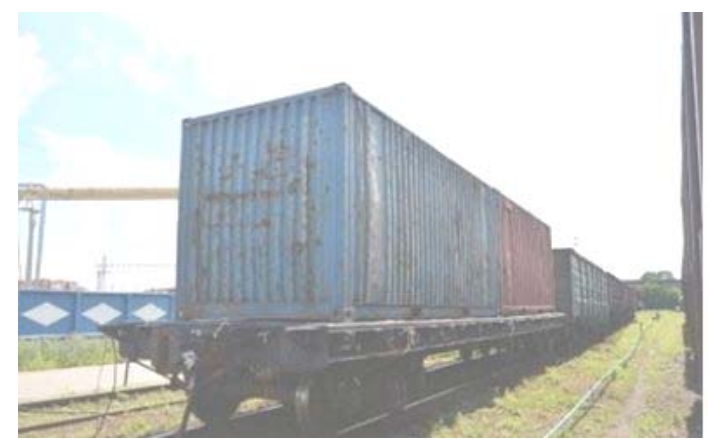

Fig. 4. Arrangement of prototype car and a retaining wall

During the collision strength tests the following parameters were recorded: collision speed, force in automatic coupler (impact force), dynamic stresses in the car elements. Collisions were made in the speed range of $5 \ldots 13 \mathrm{~km} / \mathrm{h}$. At the same time, in the course of collisions the car was periodically inspected for the structural integrity of the car, of the containers and baseplates with fitting stops.

All kinds of tests were carried out with the use of tension metering and recording equipment of DNURT on the territory of the car repair depot Chelyabinsk. Processes were recorded on electronic media (PC) with their subsequent processing. Measured strains for all kinds of tests by known methods were transformed into stresses.

The strength structure was evaluated by summing-up the stresses caused by the vertical loads due to the weight of the car cargo and containers, the estimated longitudinal tensile load by I (2.0 MN) and III (1.0 MN) design modes, the estimated longitudinal compressive load by I $(2.5$ $\mathrm{MN})$ and III (1.0 MN) design modes, the dynamic addition of the vertical load (mode III), the lateral load (III mode). The stress values due to quasistatic longitudinal loads were obtained by calculation.

When evaluating the car collision strength there were taken into account the stresses due to vertical 
load and collision longitudinal load, reduced to the force of 3.5 MN.

The main task of calculation-experimental evaluation of the structure fatigue safety was to check the compliance of flatcar structure fatigue safety index with the requirements of regulatory documentation. For this purpose the equivalent stress amplitude value was determined, that allowed calculating the endurance limit and the fatigue safety factor. When evaluating the fatigue resistance there were taken into account both the vertical and longitudinal loads. Stresses due to vertical loads were determined by car dumping from wedges (determining the stress frequency and amplitude), while stresses due to longitudinal loads were obtained in the course of the strength collision.

\section{Findings}

The results of structure strength evaluation allowed building the diagrams of stress values in the main elements taking into account the longitudinal compression and extension loads (Fig. 5).

$a$

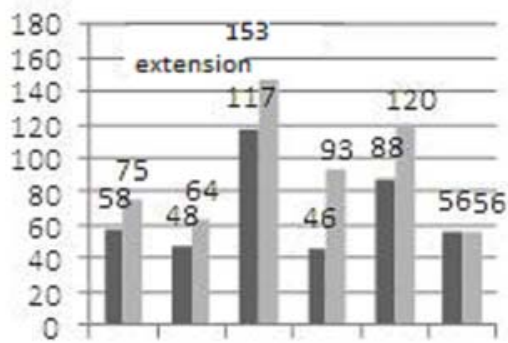

CS SS SB LB DG LBM

$b$

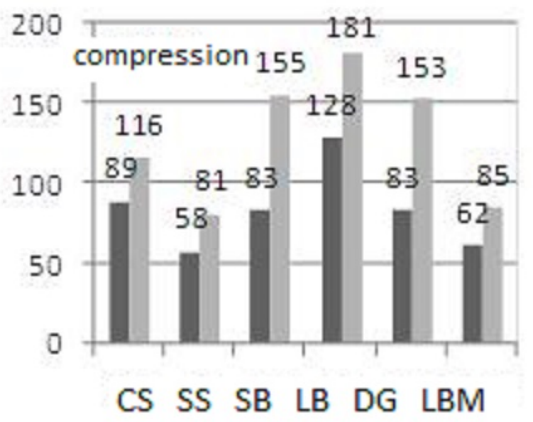

Fig. 5. Stresses (in MPa) in the flatcar elements by I and III design mode: $a$ - extension; $b$ - compression
The lighter shade in the figure marks the stresses by I design mode, the darker one - by III design mode, the designation of elements corresponds to Fig. 2.

The figure shows that the most stressful elements are the span bolster, the cross-bearers and the diagonal. Herewith the value of total stresses by I design mode under longitudinal compressive loads is higher and reaches $181 \mathrm{MPa}$ in the crossbearer. It should be noted that while the tensile loads result mostly in strained span bolster, the compressive ones force the work of cross-bearer and centre sill (I mode). Weak entry into operation of side sills also may be noted - the maximum stress under compressive load was $81 \mathrm{MPa}$. In general, the concerned flatcars are characterized by a low level of stresses, and their values are significantly lower than the permitted ones in both design modes (Table 1).

Table 1

The values of allowable stresses in the elements

\begin{tabular}{l|c|c|c}
\hline \multirow{2}{*}{ Element } & \multicolumn{2}{|c}{ Allowable stresses by modes, MPa } \\
\cline { 2 - 3 } & \multicolumn{2}{|c}{ I } & III \\
\cline { 2 - 3 } & $\begin{array}{c}\text { extension/ } \\
\text { compres- } \\
\text { sion }\end{array}$ & impact & \\
\hline $\begin{array}{l}\text { Centre sill } \\
\text { and span } \\
\text { bolsters }\end{array}$ & 274.5 & 305 & 190 \\
$\begin{array}{l}\text { Side sill and } \\
\text { cross beams }\end{array}$ & 289.75 & 305 & 195 \\
\hline
\end{tabular}

The evaluation results of the car collision strength with the longitudinal force of $3.5 \mathrm{MN}$ are shown in Fig. 6. The stresses in 4012-50 model flatcar elements are shown in grey, those of 401-50 model - in black. Designation of elements corresponds to Fig. 2.

The diagram shows that the most stressful elements are the span bolster, the frame longitudinal beams and the diagonal - 189...252 MPa. The active entry into operation of 4012-50 model flatcar side sills should be noted (174 MPa), while 401250 model has the stress level in the centre sill by $23 \%$ lower than in the side sill. This can be attributed to a difference in frame structural variations. Since the longitudinal force value of $3.5 \mathrm{MN}$ results in operation of the car element metal in the range of low-cycle fatigue, then the allowable 
stresses [б] $=\sigma_{\mathrm{T}}=305 \mathrm{MPa}$ (see Table 1). In general, the stress values in the flatcar elements, when the impact force is $3.5 \mathrm{MPa}$, are lower than the permitted ones.

The results of calculation-experimental evaluation of the structure fatigue safety showed that the value of the fatigue safety factor is above the regulatory value (1.5) in all sections of the flatcar elements. Fig. 7 shows the diagrams of fatigue safety factor values for the car basic elements. Fig. $7 a$ corresponds to the model 4012-50, Fig. $7 b-401$ 50. Here the darker line shows the minimum values, while the lighter line - the maximum values of the fatigue safety factor, designation of the elements corresponds to Fig. 2.

Maximum and minimum values of fatigue safety factor are recorded in the same section of the structural elements. The diagram shows that the distribution nature of safety factor values along the flatcars is the same. The minimum fatigue safety factor values for 4012-50 model are in the range of $1.61 \ldots 1.97$, while for 401-50 model are a little lower $-1.51 \ldots 1.82$. But for both models the fatigue safety factor values are not lower than the regulatory ones (1.5).

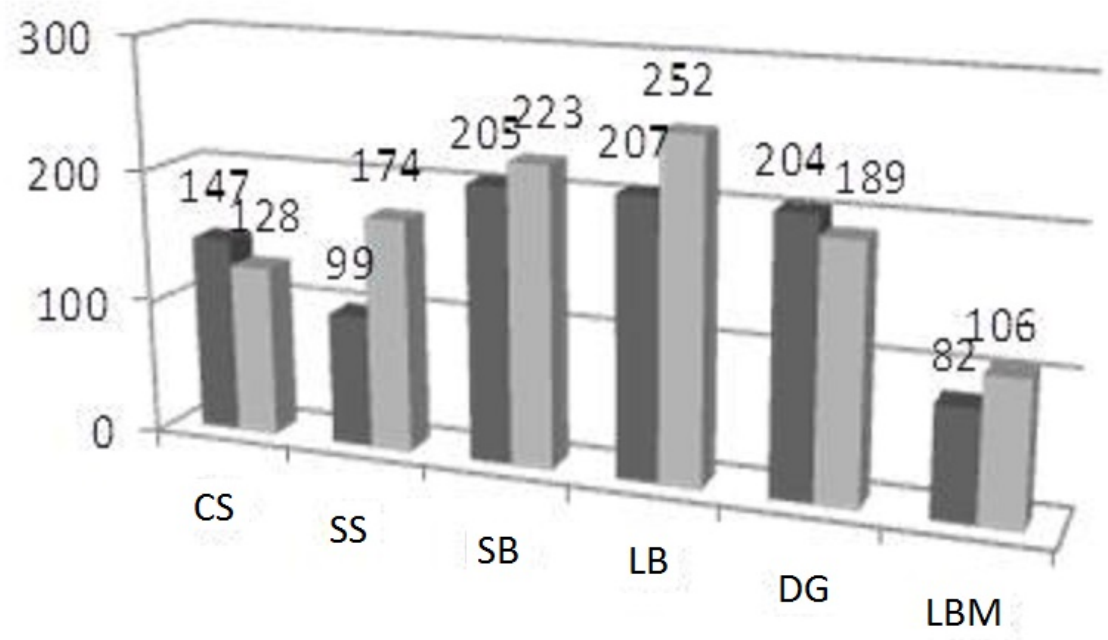

Fig. 6. Collision stress values (vertically, MPa) in the flatcar elements

$a$

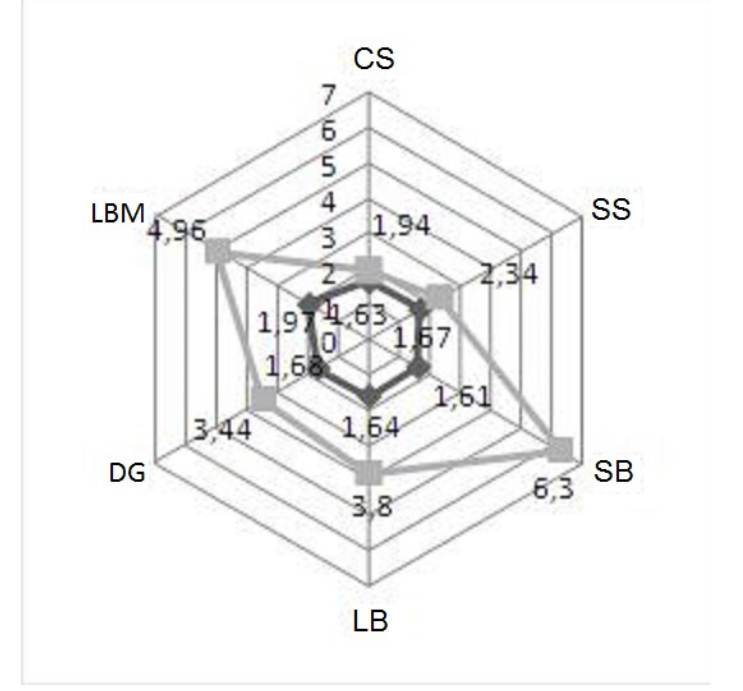

$b$

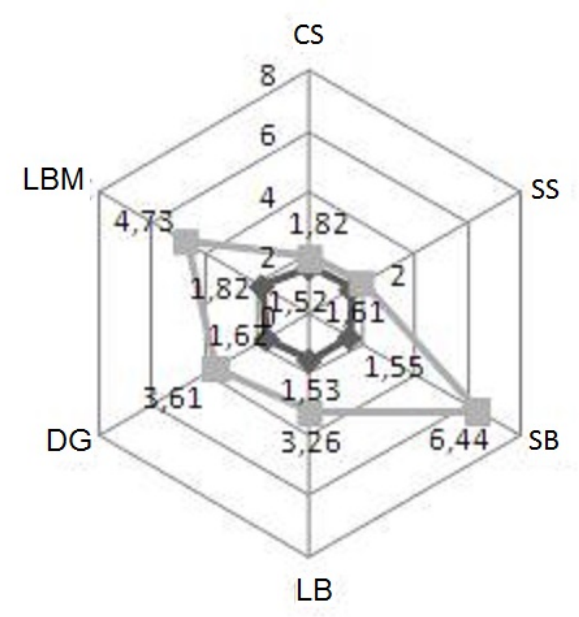

Fig. 7. Diagram of fatigue safety factor values of the flatcar elements 


\section{Originality and practical value}

The results of the conducted static and impact tests, computation-experimental evaluation of the structure fatigue safety factor for flatcar models 4012-50 and 401-50 verified compliance of the modernized flatcars with regulatory requirements. The research results can be the basis for the removal of flatcars from reserve and their reequipment for transportation of large containers.

These positive results of prototype tests after the modernization performed during the scheduled repairs in six car-repair depots allow these depots to re-equip the flatcars of the mentioned models commercially.

\section{Conclusions}

The conducted research provided rationalization for modernization of universal flatcars for container service according to TU 3182-06571390252-2911 in the conditions of the car-repair enterprises. This makes it possible to use the rolling stock cars that are out of operation.

\section{LIST OF REFRENCE LINKS}

1. Битюцкий, А. А. Оценка эффективности сочлененных контейнерных платформ / А. А. Битюцкий // Вагонный парк. - 2013. - № 10. C. 34-38.

2. Бороненко, Ю. П. Динамические испытания контейнеров при продольных соударениях / Ю. П. Бороненко, А. М. Орлова, А. Н. Смирнов // Опасные грузы и контейнеры. - 2004. № 1-2. - C. 50-53.

3. Бороненко, Ю. П. Динамические испытания на продольные соударения контейнеров и вагонов для их перевозки / Ю. П. Бороненко, А. М. Орлова, А. Н. Смирнов // Экспериментальное кольцо ВНИИЖТ-70 : тез. докл. Междунар. конф. - Щербинка, 2002. - С. 141-142.

4. Бороненко, Ю. П. Модернизация и переоборудование грузовых вагонов - путь к повышению эффективности грузоперевозок / Ю. П. Бороненко, Е. М. Попов // Инновации в эксплуатации и развитии инфраструктуры железнодорожного транспорта : науч.-практ. конф. / ВНИИЖТ. - Москва, 2004. - С. 6-7.

5. Бубнов, В. М. Совершенствование конструкции подвижного состава для перевозки контейнеров / В. М. Бубнов, С. В. Мямлин, Н. Л. Гуржи // Вісн. Дніпропетр. нац. ун-ту залізн. трансп. ім. акад. В. Лазаряна. Дніпропетровськ, 2009. - Вип. 26. - С. 11-14.
6. Морчиладзе, И. Г. Совершенствование вагонов-платформ для международной перевозки контейнеров. / И. Г. Морчиладзе, А. В. Третьяков, А. М. Соколов // Железные дороги мира. 2006. - № 8. - C. 52-55.

7. Мямлин, С. В. Перевозка контейнеров железнодорожным транспортом / С. В. Мямлин, А. В. Шатунов, А. В. Сороколет // Проблеми та перспективи розвитку залізн. трансп. : тези доп. 70 Міжнар. наук.-практ. конф. (15.0416.04.2010) / Дніпропетр. нац. ун-т залізн. трансп. ім. акад. В. Лазаряна, Схід. наук. центр трансп. акад. України. - Дніпропетровськ, 2010. - C. 76-77.

8. Мямлин, С. В. Повышение грузоподъемности вагонов-платформ для перевозки контейнеров / С. В. Мямлин, В. М. Бубнов, Н. Л. Андрющенко // Подвижной состав XXI века: идеи, требования, проекты : тез. докл. V междунар. науч.техн. конф. (4.06-6.06.2007) / Петербург. гос. ун-т путей сообщ. - Санкт-Петербург, 2007. C. $42-44$.

9. Нормы для расчета и проектирования вагонов железных дорог МПС колеи 1520 мм (несамоходных). - Москва : ГосНИИВ : ВНИИЖТ, 1996. $-354 \mathrm{c}$.

10. Об улучшении использования универсальных платформ / А. Г. Рейдемейстер, В. А. Калашник, В. Ю. Подлубный [и др.] // Проблеми та перспективи розвитку залізн. трансп. : тези 74 Міжнар. наук.-практ. конф. (15.05-16.05.2014)/ Дніпропетр. нац. ун-т залізн. трансп. ім. акад. В. Лазаряна. - Дніпропетровськ, 2014. C. $85-86$.

11. Орлова, А. М. Исследование динамических качеств сочленённого вагона-платформы на математических моделях / А. М. Орлова, Е. А. Рудакова / Вісн. Дніпропетр. нац. ун-ту залізн. трансп. ім. акад. В. Лазаряна. Дніпропетровськ, 2008. - Вип. 23. - С. 85-88.

12. Шайтанова, И. К. Выбор направлений модернизации универсальных вагонов-платформ / И. К. Шайтанова // Изв. Петербург. ун-та путей сообщ. - Санкт-Петербург, 2005. - Вып. 1. C. 65-70.

13. Cichy, R. Wymagania TSI «tabor kolejowy- wagony tovarowe» do prezwozu naczep drogowych $\mathrm{w}$ systemach intermodalnych / R. Cichy, M. Medwid / Pojazdy Szynove. - 2012. - № 3. - P. 40-44.

14. Czaplicki, J. M. On the system: truck-workshop in the queue theory terms / J. M. Czaplicki // Maintenance and Reliability. - 2007. - № 3 (35). P. $7-10$.

15. Stoilov, V. Study of fatigue in welded joints and stress notches of wagon series $\mathrm{s}(\mathrm{g}) \mathrm{mmns}$ with

(C) O. H. Reidemeister, V. O. Kalashnyk, O. A. Shykunov, 2016 
methods of UIC and DVS 1612 [Electronic resource] / V. Stoilov, S. Slavchev, S. Purgic. P. 66-69. - Available at: http://www.mech-
ing.com/journal/Archive/2012/9/nano/82_Stoilov $\% 20 \mathrm{~d} 1 \% 20 \mathrm{en}$ tm'12.pdf. Title from the screen. Accessed : 24.02.2016.

\section{О. Г. РЕЙДЕМЕЙСТЕР ${ }^{1}$, В. О. КАЛАШНИК ${ }^{2 *}$, О. А. ШИКУНОВ ${ }^{3}$}

${ }^{1}$ Каф. «Вагони та вагонне господарство», Дніпропетровський національний університет залізничного транспорту імені академіка В. Лазаряна, вул. Лазаряна, 2, Дніпропетровськ, Україна, 49010, тел. /факс +38 (056) 79319 16, ел. пошта reidemeister@mail.ru, ORCID 0000-0001-7490-7180

${ }^{2 *}$ Каф. «Вагони та вагонне господарство», Дніпропетровський національний університет залізничного транспорту імені академіка В. Лазаряна, вул. Лазаряна, 2, Дніпропетровськ, Україна, 49010, тел. /факс +38 (056) 79319 16, ел. пошта kv47@i.ua, ORCID 0000-0002-8073-4631

${ }^{3}$ Каф. «Вагони та вагонне господарство», Дніпропетровський національний університет залізничного транспорту імені академіка В. Лазаряна, вул. Лазаряна, 2, Дніпропетровськ, Україна, 49010, тел. /факс +38 (056) 793 19 16, ел. пошта tri_s@ua.fm, ORCID 0000-0001-8256-2634

\section{МОДЕРНІЗАЦІЯ ЯК СПОСІБ ПОЛІПШЕННЯ ВИКОРИСТАННЯ УНІВЕРСАЛЬНИХ ВАГОНІВ}

Мета. Основними вимогами до конструкції модернізованих вагонів є ті, які дозволять знизити експлуатаційні витрати та підвищити економічну ефективність їх використання. У зв'язку з актуальністю цієї тематики необхідно провести комплекс досліджень, який дозволить у подальшому використовувати універсальні платформи, переобладнані відповідно до Технічних умов ТУ 3182-065-71390252-2911 під перевезення контейнерів. У процесі досліджень передбачається виконати: оцінку міцності, запасу опору втоми елементів конструкції та оцінку відповідності характеристик елементів модернізованої платформи нормативній документації. Методика. Проведено аналіз використання для перевезення контейнерів спеціалізованого та універсального рухомого складу, питань модернізації універсальних вагонів. Виконано оцінку міцності несучої конструкції платформ на підставі комплексу розрахункових і експериментальних досліджень. Експериментальна частина включає в себе випробування: статичні, ударні та на ремонтні навантаження. Проведено оцінку якостей вагона на міцність і запасу втомної міцності на базі розрахунково-експериментальних даних. Результати. На підставі проведених статичних, ударних та на ремонтні навантаження випробувань, із урахуванням квазістатичних поздовжніх сил, проведена оцінка міцності конструкції вагонів згідно нормативної документації. Розрахунково-експериментальні дані дозволяють зробити оцінку запасу опору втоми елементів конструкції. Дана робота завершена отриманням результатів, які дозволяють обгрунтовано здійснювати переобладнання універсальних платформ опорними плитами з фітинговими упорами для кріплення контейнерів. Наукова новизна. Результати проведених розрахункових та експериментальних досліджень показали, що модернізовані платформи відповідають умовам міцності й мають достатній запас опору втоми. Це дозволяє рекомендувати переобладнання універсальних платформ серійно всім вагоноремонтним підприємствам, що представили дослідні зразки. Практична значимість. Авторами проведений комплекс робіт, на підставі яких обгрунтована можливість переобладнання універсальних платформ під перевезення великотоннажних контейнерів. Частина вагонного парку, що знаходиться в запасі, з невеликими матеріальними витратами може бути переведена в експлуатаційний парк. За рахунок проведеної модернізації - переобладнання універсальних платформ стаціонарними спеціалізованими пристроями, - збільшується коефіцієнт використання вагона.

Ключові слова: платформа; контейнер; хребтова балка; міцність конструкції; статичні випробування; поздовжні навантаження; ударні випробування; фітинговий упор; напруження; оцінка міцності

\section{А. Г. РЕЙДЕМЕЙСТЕР ${ }^{1}$, В. А. КАЛАШНИК ${ }^{2 *}$, А. А. ШИКУНОВ ${ }^{3}$}

${ }^{1}$ Каф. «Вагоны и вагонное хозяйство», Днепропетровский национальный университет железнодорожного транспорта имени академика В. Лазаряна, ул. Лазаряна, 2, Днепропетровск, Украина, 49010, тел. /факс +38 (056) 7931916 , эл. почта reidemeister@mail.ru, ORCID 0000-0001-7490-7180

${ }^{2 *}$ Каф. «Вагоны и вагонное хозяйство», Днепропетровский национальный университет железнодорожного транспорта имени академика В. Лазаряна, ул. Лазаряна, 2, Днепропетровск, Украина, 49010, тел. /факс +38 (056) 7931916 , эл. почта kv47@i.ua, ORCID 0000-0002-8073-4631

${ }^{3}$ Каф. «Вагоны и вагонное хозяйство», Днепропетровский национальный университет железнодорожного транспорта 
имени академика В. Лазаряна, ул. Лазаряна, 2, Днепропетровск, Украина, 49010, тел. /факс +38 (056) 7931916 , эл. почта tri_s@ua.fm, ORCID 0000-0001-8256-2634

\section{МОДЕРНИЗАЦИЯ КАК СПОСОБ УЛУЧШЕНИЯ ИСПОЛЬЗОВАНИЯ УНИВЕРСАЛЬНЫХ ВАГОНОВ}

Цель. Основными требованиями к конструкции модернизированных вагонов являются те, которые позволят снизить эксплуатационные расходы и повысить экономическую эффективность их использования. В связи с актуальностью данной тематики необходимо провести комплекс исследований, который позволит в дальнейшем использовать универсальные платформы, переоборудованные согласно Техническим условиям ТУ 3182-065-71390252-2911 под перевозку контейнеров. В процессе исследований предполагается произвести: оценку прочности, запаса сопротивления усталости элементов конструкции и оценку соответствия прочностных характеристик элементов модернизированной платформы нормативной документации. Методика. Проведен анализ использования для перевозки контейнеров специализированного и универсального подвижного состава, вопросов модернизации универсальных вагонов. Выполнена оценка прочности несущей конструкции платформ на основании комплекса расчетных и экспериментальных исследований. Экспериментальная часть включает в себя испытания: статические, ударные и на ремонтные нагрузки. Произведена оценка прочностных качеств вагона и запаса усталостной прочности на базе расчетноэкспериментальных данных. Результаты. На основании проведенных статических, ударных и на ремонтные нагрузки испытаний, с учетом квазистатических продольных сил, произведена оценка прочности конструкции вагонов согласно нормативной документации. Расчетно-экспериментальные данные позволяют произвести оценку запаса сопротивления усталости элементов конструкции. Данная работа завершена получением результатов, которые позволяют обоснованно производить переоборудование универсальных платформ опорными плитами с фитинговыми упорами для крепления контейнеров. Научная новизна. Результаты проведенных расчетных и экспериментальных исследований показали, что модернизированные платформы отвечают условиям прочности и имеют достаточный запас сопротивления усталости. Это позволяет рекомендовать переоборудование универсальных платформ серийно всем вагоноремонтным предприятиям, представившим опытные образцы. Практическая значимость. Авторами проведен комплекс работ, на основании которых обоснована возможность переоборудования универсальных платформ под перевозку крупнотоннажных контейнеров. Часть вагонного парка, находящаяся в запасе, с небольшими материальными затратами может быть переведена в эксплуатационный парк. За счет проведенной модернизации переоборудования универсальных платформ стационарными специализированными устройствами, увеличивается коэффициент использования вагона.

Ключевые слова: платформа; контейнер; хребтовая балка; прочность конструкции; статические испытания; продольные нагрузки; ударные испытания; фитинговый упор; напряжения; оценка прочности

\section{REFERENCES}

1. Bityutskiy A.A. Otsenka effektivnosti sochlenennykh konteynernykh platform [Evaluating the efficiency of the coupled container platforms]. Vagonnyy park - Car Fleet, 2013, no. 10, pp. 34-38.

2. Boronenko Yu.P., Orlova A.M., Smirnov A.N. Dinamicheskiye ispytaniya konteynerov pri prodolnykh soudareniyakh [Dynamic tests of containers at longitudinal collisions]. Opasnyye gruzy $i$ konteynery Dangerous Cargoes and Containers, 2004, no. 1-2, pp. 50-53.

3. Boronenko Yu.P., Orlova A.M., Smirnov A.N. Dinamicheskiye ispytaniya na prodolnyye soudareniya konteynerov i vagonov dlya ikh perevozki [Dynamic tests for longitudinal collisions of containers and cars for their transportation]. Tezisy dokladov Mezhdunarodnoy konferentsii «Eksperimentalnoye koltso VNIIZhT-70» [Proc. of Intern. Conf. «Test Loop ARSRIRT-70»]. Shcherbinka, 2002, pp. 141-142.

4. Boronenko Yu.P., Popov Ye.M. Modernizatsiya i pereoborudovaniye gruzovykh vagonov - put k povysheniyu effektivnosti gruzoperevozok [Modernization and re-equipment of freight cars is a way to improve the efficiency of freight transportations]. Nauchno-prakticheskaya konferentsiya "Innovatsii $v$ ekspluatatsii i razvitii infrastruktury zheleznodorozhnogo transporta» [Sci. and Practical Conf. «Innovations in service and railway transport infrastructure development»]. Moscow, 2004, pp. 6-7.

5. Bubnov V.M., Myamlin S.V., Gurzhi N.L. Sovershenstvovaniye konstruktsii podvizhnogo sostava dlya perevozki konteynerov [The improvement of the rolling stock design for containers transportaion]. Visnyk Dnipropetrovskoho natsionalnoho universytetu zaliznychnoho transportu imeni akademika V. Lazariana 
[Bulletin of Dnipropetrovsk National University of Railway Transport named after Academician V. Lazaryan], 2009, issue 26, pp. 11-14.

6. Morchiladze I.G., Tretyakov A.V., Sokolov A.M. Sovershenstvovaniye vagonov-platform dlya mezhdunarodnoy perevozki konteynerov [Improvement of the flat cars for the international transportation of containers]. Zheleznyye dorogi mira - Railways of the World, 2006, no. 8, pp. 52-55.

7. Myamlin S.V., Shatunov A.V., Sorokolet A.V. Perevozka konteinerov zheleznodorozhnym transportom [Transportation of containers by railway transport]. Tezy dopovidei 70 Mizhnarodnoi naukovo-praktychnoi konferentsii «Problemy ta perspektyvy rozvytku zaliznychnoho transpotu» [Theses of the $70^{\text {th }}$ Int. Sci. and Practical Conf. «Problems and prospects of railway transport development»]. Dnipropetrovsk, 2010, pp. 76-77.

8. Myamlin S.V., Bubnov V.M., Andryushchenko N.L. Povysheniye gruzopodyemnosti vagonov-platform dlya perevozki konteynerov [Increasing the carrying capacity of flat cars for transportation of containers]. Tezisy dokladov $V$ mezhdunarodnoy nauchno-tekhnicheskoy konferentsii «Podvizhnoy sostav XXI veka: idei, trebovaniya, proekty» [Theses of the 5th Int. Sci. and Techn. Conf. «Rolling stock of the XXI century: ideas, requirements, and projects»]. Saint Petersburg, 2007, pp. 42-44.

9. Normy dlya rascheta i proektirovaniya vagonov zheleznykh dorog MPS kolei $1520 \mathrm{~mm}$ (nesamokhodnykh) [The rules for calculation and design of (unpowered) cars of the Transportation Ministry with the track 1520 mm]. Moscow, GosNIIV-VNIIZhT Publ., 1996. 354 p.

10. Reydemeyster A.G., Kalashnik V.A., Podlubnyy V.Yu. Ob uluchshenii ispolzovaniya universalnykh platform [About the use improvement of the multi-purpose platforms]. Tezy 74 Mizhnarodnoi naukovo-praktychnoi konferentsii «Problemy ta perspektyvy rozvytku zaliznychnoho transpotu» [Theses of the 74th Intern. Sci. and Practical Conf. «Problems and prospects of railway transport development»]. Dnipropetrovsk, 2014. pp. 8586.

11. Orlova A.M., Rudakova Ye.A. Issledovaniye dinamicheskikh kachestv sochlenennogo vagona-platformy na matematicheskikh modelyakh [The study of the dynamic properties of the articulated flat-car on mathematical models]. Visnyk Dnipropetrovskoho natsionalnoho universytetu zaliznychnoho transportu imeni akademika $V$. Lazariana [Bulletin of Dnipropetrovsk National University of Railway Transport named after Academician V. Lazaryan], 2008, issue 23, pp. 85-88.

12. Shaytanova I.K. Vybor napravleniy modernizatsii universalnykh vagonov-platform [Selection the modernization directions of the multi-purpose flat cars]. Izvestiya Peterburgskogo universiteta putey soobshcheniya [Bulletin of the Saint Petersburg University of Communication Lines], 2005, issue 1, p. 65-70.

13. Cichy R., Medwid M. Wymagania TSI «tabor kolejowy- wagony tovarowe» do prezwozu naczep drogowych w systemach intermodalnych. Pojazdy Szynove, 2012, no. 3, pp. 40-44.

14. Czaplicki J.M. On the system: truck-workshop in the queue theory terms. Maintenance and Reliability, 2007, no. 3 (35), pp. 7-10.

15. Stoilov V., Slavchev S., Purgic S. Study of fatigue in welded joints and stress notches of wagon series s (g)mmns with methods of UIC and DVS 1612, pp. 66-69. Available at: http://www.meching.com/journal/Archive/2012/9/nano/82_Stoilov\%20d1\%20en_tm'12.pdf(Accessed: 24 February 2016).

Chief Research Associate V. L. Horobets, Dr. Sc. (Tech) (Ukraine); Chief Structural Engineer of PJSC «Dneprovagonmash»Dolynskyi $S$. V. (Tech) (Ukraine) recommended this article to be published

Received: Jan. 14, 2016

Accepted: March 22, 2016 